\title{
Power, Resistance and Development in the Global South: Notes Towards a Critical Research Agenda
}

\author{
Alf Gunvald Nilsen ${ }^{1,2,3}$
}

Published online: 17 June 2016

C The Author(s) 2016. This article is published with open access at Springerlink.com

\begin{abstract}
This article engages with radical critiques of the Eurocentric grammar of development discourses. I start from a position of considerable sympathy with their appreciation of the discursive dimensions of power that attach to the idiom of development and their solidarity with the oppositional projects of subaltern groups. However, this sympathy combines with a considerable degree of disagreement in terms of how the discursive power of development is understood and how the dynamics of popular resistance are theorised. As an alternative to the relatively crude postulation of development as a discursive regime that enables the West to exercise power over the Rest, I develop an argument that emphasises the multivalent character of the idiom of development and trace this multivalence to situated contestations that take place between opposing political projects that strive to shape the form and direction of social change in specific ways. Furthermore, I will argue that this contentious dynamic becomes particularly evident in those world-historical conjunctures when subaltern groups mobilize around social movement projects that destabilise hegemonic power relations in the capitalist world-system. To illustrate this point, I will provide a broad-brushed outline of three distinct 'development regimes' that have shaped North-South relations from the late nineteenth to the early twenty-first century and discuss the ways in which these regimes have been destabilised by the articulation of oppositional meanings of development articulated from below by progressive social movement projects. Finally, I draw on my own fieldwork experiences to reflect on how critical scholars can engage with movement projects that challenge the dominant directions and meanings of development in ways that can contribute to democratic deliberations within social movements.
\end{abstract}

Keywords Power-Resistance - Development. Global South · Social movements · Eurocentrism

Alf Gunvald Nilsen

alfgunvald@gmail.com

1 Department of Sociology, University of Bergen, Bergen, Norway

2 The Society, Work and Development Institute, University of the Witwatersrand, Johannesburg, South Africa

3 Bjørkestøl, 4790 Lillesand, Norway 


\section{Introduction}

In her seminal critique of sociological Eurocentrism, Bhambra (2007) argues that regnant historical sociological approaches to the study of modernity are founded on a conceptual deep structure that posits two foundational ruptures - one that is temporal and another that is spatial. The temporal rupture separates a traditional agrarian past from a modern industrial present and is in turn inscribed in a spatial rupture between Europe and the rest of the world as modernity is posited as a mode of societal organisation that first crystallises within a European space and then subsequently diffuses outwards to incorporate the non-western world. Ultimately, this deep structure is expressive of the foundational Orientalism of social scientific knowledge about non-western societies, the essence of which — as Said (1978, p. 42) brought home to us many years ago - is 'the ineradicable distinction between Western superiority and Oriental inferiority'. As Bhambra (2014, pp. 10-12) makes clear in her recent extension of her argument, this deep structure is also very much at the heart of the conceptual problematique that to a large extent has shaped social scientific engagements with the global South from the post-war era up to the present-namely development. For example, she points out that by distilling an ideal-typical account of social change towards modernity from the historical trajectory of the west, modernisation theory in effect 'normalised a particular trajectory of development and established a global frame within which all societies could be placed' (Bhambra 2014, p. 21).

In making this argument, Bhambra touches on concerns that have been central to radical critiques of both development as a mode of intervention and development studies as a field of scholarly inquiry since at least the 1990s (see, for example, Sachs 1992; Brohman 1995; Crush 1995). Sardar sums up the tenor of these critiques as follows:

For the idea of development to have any meaning, there must be an evaluative scale.

Development must propose that there are nations that have embraced Western technology enough to be developed; there are other nations on a slightly lower scale of civilization that are developing; and there are still other nations that, steeped in religion and tradition, reject all forms of liberalism and secularism and thus doggedly remain underdeveloped ... Development continues to mean what it has always meant: a standard by which the West measures the non-west (1999, p. 49).

In other words, development is at the core of a form of discursive power that enables and undergirds western domination in and of the world-system. For the scholars who have pioneered this critique, hope is located in the resistance that is mounted by social movements that reject the normalising power of development. '[T]hey expect nothing from development or from the money economy', writes Vandana Shiva and Maria Mies of the women that were central to India's Chipko movement in the 1970s and early 1980s: 'They want to preserve their autonomous control over their subsistence base, their common property resources: the land, water, forests, hills' (cited in Rangan 2000, p. 34).

My point of departure in this article is a considerable degree of sympathy for these critiques - in particular for their orientation towards deciphering the Eurocentric grammar of development discourses, their appreciation of the discursive dimensions power that attach to development as an idiom, and their solidarity with the oppositional projects of subaltern groups. However, this sympathy combines with a considerable degree of disagreement in terms of how the discursive power of development is understood and how the dynamics of popular resistance are theorised. In this article, I synthesise insights from critical responses to 
post-development theory in order to put forward some possible conceptual building blocks for a research agenda that constitutes an alternative to the relatively crude postulation of development as a discursive regime that enables the West to exercise power over the Rest. In doing so, I seek to develop an argument that emphasises the multivalent character of the idiom of development and trace this multivalence to situated contestations that take place between opposing political projects that strive to shape the form and direction of social change in specific ways (see Nilsen 2015a). Furthermore, I will argue that this contentious dynamic becomes particularly evident in those world-historical conjunctures when subaltern groups mobilise around 'social movement projects' (Cox and Nilsen 2014) that destabilise hegemonic power relations in the capitalist world-system. To illustrate this point, I will provide a broadbrushed outline of three distinct 'development regimes' (Ludden 1992) that have shaped North-South relations from the late nineteenth to the early twenty-first century and the ways in which these regimes have been destabilised by the articulation of oppositional meanings of development through progressive social movement projects. Finally, I draw on my own fieldwork experiences to reflect on how critical scholars can engage with movement projects that challenge the dominant directions and meanings of development in ways that can contribute to democratic deliberations within social movements.

\section{The Power of Development?}

As I have already pointed out, the 1990s witnessed the emergence of a particular form of radical critique in the field of development research. Scholars like Gustavo Esteva, Arturo Escobar, Majid Rahnema and Gilbert Rist went far beyond earlier radical interventions in questioning the meaning of 'development' as an idiom with any relevance to political projects for progressive social change. The nature of the critique is aptly summed up in a recent restatement of Esteva's famously harsh verdict on the development project: 'If you live in Rio or Mexico City today, you need to be very rich or very numb to fail to notice that development stinks' (Esteva et al. 2013, p. 261). The critique was centred on the claim that development was an idiom that converted the modernisation of the western world into a universal model of and yardstick for social change, which was then imposed upon peoples and societies in the South through powerful institutions in which western powers predominate, thus enabling the North to exercise power over the South, and in doing so, erasing the specific character of these peoples and these societies (see Rahnema and Bawtree 1997).

It was arguably in the work of Arturo Escobar-and especially his book Encountering Development, which set the terms of debate in the field of critical development research for a considerable period of time after its publication in 1995 - that this critique was developed to its fullest extent. Drawing on Foucault's theories of discursive power, Escobar (1995, p. 10) argued for the need to understand how forms of knowledge about what development is, systems of institutional power through which those forms of knowledge come to operate on the world, and the subjectivities through which people come to understand themselves are fused in a 'development discourse' that ultimately constitutes 'an efficient apparatus that systematically relates forms of knowledge and techniques of power'. The development discourse, Escobar argues, originated in the post-war era - its arrival was signalled by Harry S. Truman's inaugural address as president of the USA in 1949 - and, due to its strict reliance on Western forms of knowledge, it has disqualified and marginalised 'non-Western knowledge systems' (Escobar 1995, p. 13). For Escobar, a progressive future is not to be forged through the construction of 'development alternatives, but in alternatives to development, that is, the 
rejection of the entire paradigm altogether' (Escobar 1995, p. 215). And it is social movements that will craft these alternatives to development: 'Social movements and anti-development struggles may contribute to the formation of nuclei of problematised social relations around which novel cultural productions might emerge' (Escobar 1995, p. 216).

Escobar's critique of the development discourse - and, in extension of this, the postdevelopment perspective more generally - has been subjected to wide-ranging critiques since the publication of Encountering Development. ${ }^{1}$ There is no need to revisit those critiques in any great detail here, but I wish to highlight two key points in this debate that will shape the argument that I am making in this article. The first point relates to an observation that many scholars have made about how subaltern groups and social movements relate to discourses and practices of development: a wide range of studies - both of the micropolitics of everyday development encounters (see, for example, Moore 1998, 1999; Li 1999; Gidwani 2002; Shakya and Rankin 2008) and of large-scale social movements (see, for example, Rangan 2000; Sinha 2003; Nilsen 2010; Vergara-Camus 2014) — have established that subaltern groups do not oppose or reject development in its entirety, but rather seek to negotiate and change the direction and meaning of development. In extension of this, and drawing on Cooper and Packard's (1997, p. 4) argument, the second point is that development is not a simply a monolithic discursive regime through which dominant social forces exercise power over subaltern social forces, but rather an inherently multivalent idiom that can be at the centre of both 'a discourse of control' (in a hegemonic inflection) and 'a discourse of entitlement' (in an oppositional inflection) - and the encounter between such discourses in and through conflicting political projects in turn give shape and form to development as a trajectory of sociohistorical change. These insights may be simple in and of themselves, but it is nevertheless my contention that they can help us to understand development — both as a discourse and as a trajectory of sociohistorical change — in a far more nuanced way than what post-development theory allows for.

Towards that end, I want to propose that discourses of control in which development constitutes the semiotic locus are best thought of as an integral dimension of what David Ludden (1992, p. 252) has referred to as 'development regimes' - that is, the 'institutionalized configuration within a state system ideologically committed to progress that draws its material sustenance from the conduct of development'. Drawing on Ferguson's (1990) crucial arguments, I also want to suggest that the exercise of power in and through development regimes occurs above all through depoliticisation - that is, by constructing a universe of meaning in which the specific deficiencies that are to be rectified by development are portrayed as purely technical problems and the interventions through which this is to be done as purely technical solutions. 'Questions that are rendered technical', Li (2007, p. 7) rightly notes, 'are simultaneously rendered nonpolitical' - and this is precisely the point: as soon as poverty, for example, becomes a technical problem that is primarily understood in terms of the shortcomings of the poor individual or the poor household rather than the relations of power that generate impoverishment for some social groups and enrichment for others, the form and direction that social change assumes in a specific spatiotemporal context is removed from the sphere of political contestation and situated within the safe - that is, apolitical - parameters of scientific expertise and bureaucratic management (see Mosse 2010; Hickey and Du Toit 2014; Harriss 2007).

Conversely, discourses of entitlement woven around development as a locus of oppositional meaning- and claims-making are best thought of as the outcome of subaltern assertions that range from quotidian subversions of development interventions to counterhegemonic

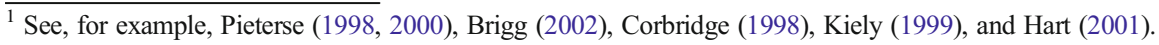


movements that seek to advance systemic transformations (see Rankin 2009, p. 224). Such meaning- and claims-making is animated by the concrete ways in which subaltern groups appropriate 'the rhetoric of development' (Gupta 2000, p. 16) and inflect it with meanings that express their grievances, needs, interests and aspirations in order to make claims on dominant groups - whether these are NGOs, governments, or multilateral institutions. What is crucial about this dynamic is the fact that it repoliticises the meaning of development: the claims that are made by subaltern groups will tend to revolve around demands for redistribution or recognition in some form or the other and with these demands the contours of the power relations that dominant inflections of the idiom have occluded will start to reappear and to be called into question. Indeed, as Moore (1998) has ably demonstrated, subaltern demands often delegitimise dominant meanings of development by calling attention to discrepancies between state ideologies and lived realities (see, also, Nilsen 2010, Chap. 8). Dominant groups will more often than not be compelled to accommodate such challenges through concessions that respond to subaltern demands to lesser or greater extents - if only to ensure the reproduction of hegemony. ${ }^{2}$ Such concessions can take the form of adjustments in the ways that development interventions are carried out in specific locales - as has been chronicled by Li (1999) in Indonesia and Sharma (2008) in India - or of reforms that are substantial enough to alter the political economy of national developmental trajectories (see Sandbrook et al. 2010). The point is that development reemerges as a contested idiom and a conflictual trajectory (see Motta and Nilsen 2011).

In sum, this proposed orientation retains the concern with the dynamic relations of power and resistance that has been central to the radical critique of development since the 1990s, but modifies it in two crucial ways. Firstly, it understands power in less absolute and unitary terms than what post-development theory does: whereas power is constantly exercised through discourses of development, it is also constantly challenged and as a result reshaped - the power of development does not simply mould the global South in its own Eurocentric image. Secondly, it also understands resistance in less absolute and unitary terms that what post-development theory does: resistance is not simply an assertion of otherness that rejects development; rather, it is a practice of meaning- and claims-making that hinges on oppositional appropriations of dominant symbols and idioms. I would emphasise that to think of resistance in this way is not to belittle its character or significance. As heroic and therefore appealing as the figure of the autonomous subaltern may be, she ultimately pales into insignificance when compared with the actually existing subaltern and her tenacious capacity for turning instruments of domination into weapons of struggle. Thus, when we confront subalterns who construct their imaginaries of a tomorrow that is different from today through inversions of the dominant meanings of development, the genuinely radical position, as De Vries (2007, p. 27) proposes, is to take these imaginaries seriously as expressions of 'the capacity to desire a different kind of society that is not yet defined'.

\section{Struggles Over Development in World-Historical Perspective}

\section{Colonial Development Versus Anti-colonial Nationalism}

The modern idea of development did indeed originate at the centre of a discourse of control, but its historical point of origin is not - as Escobar would have it - the post-war era and

\footnotetext{
${ }^{2}$ As I have pointed out in more detail elsewhere, the making of concessions is at the heart of hegemonic processes (Nilsen 2015b; see also Roseberry 1994; Mallon 1995; Gramsci 1998).
} 
Truman's inaugural speech of 1949. Rather, as Cowen and Shenton (1996, p. 110) have argued, the modern idea of development initially emerged in the first half of the nineteenth century as a response to 'the disillusionment with the promise of potentially infinite improvement' associated with the rise of capitalism. In the core of the capitalist world system, this disillusionment was directly related to the dispossession of subaltern groups through the process that Marx (1990, p. 873) referred to as 'primitive accumulation'-a process that threw up an unruly surplus population that was seen as a threat to social and political order (see, for example, Rediker and Linebaugh 2001). In this context, development - understood as deliberate interventions geared towards governing the form and direction of social change-was intended 'to compensate for the negative propensities of capitalism through the reconstruction of social order' (Cowen and Shenton 1996, p. 111).

The early decades of the twentieth century witnessed the globalisation of the development doctrine as colonial states increasingly came to concentrate and coordinate their efforts to 'manage rural livelihoods' and 'to order, control and compel the progress of their most backward subjects' (Beusekom and Hodgson 2000, p. 30). ${ }^{3}$ The crystallisation of a colonial development regime occurred in the aftermath of a series of devastating famines that swept across Asia, Africa and Latin America in the late 1800s and left as many as 60 million people dead. As Davis (2002) has noted, the millions who perished in these 'late Victorian holocausts' were overwhelmingly peasants whose livelihoods had been eroded due to the unequal terms on which they had been integrated into the circuits of global commodity exchange. With the onset of the twentieth century, colonial states witnessed both an increased influx of rural populations to urban centres where they congealed as nascent working classes and the gradual consolidation of anti-colonial nationalism. It was in this context that Asia and Africa saw the coming into being of a development regime that sought to shore up the legitimacy of empire by 'bringing together a range of interventionist policies and metropolitan finance with the explicit goal of raising colonial standards of living' (Cooper and Packard 1997, p. 7).

Colonial development interventions spanned a wide register of fields, from health and education, via community development and resettlement schemes, to agricultural modernisation (see, for example, Worby 2000; Hodgson 2000; Beusekom 1997; Smyth 2004). After World War II, the scale and intensity of these interventions increased as governmental and bureaucratic infrastructures were expanded and funding was augmented in order to bring scientific and technical expertise to bear on colonial subjects and territories (Cooper 1997; Beusekom and Hodgson 2000). Grischow's (2001) study of the Gonja Development Project in the Gold Coast - a massive scheme to promote agricultural modernisation in the country's Northern Territories - brings out the way in which these interventions fused the economic and political imperatives that colonial authorities confronted, but at the same time sought to depoliticise questions of development in a context where anti-colonial nationalism was gaining ground. In a nutshell, the project sought to resettle rural populations on an unoccupied tract of land in the western Gonja region of the Northern Territories and to promote mechanised groundnut production. Whereas the key motivation for this intervention was Britain's desperate need for access to oilseeds and proteins in the context of the post-war sterling crisis, the

\footnotetext{
${ }^{3}$ In the Indian context, Ludden (2005) proposes that the rudiments of a colonial development regime was in place as early as the 1880 s, when colonial governance came increasingly to be concentrated around four key precepts: (i) that the state should lead development processes in the public interest; (ii) that the state should invest in infrastructure to boost private enterprise; (iii) that developmental progress should benefit the poor, for example by shielding them from the risk of famine; and (iv) that advances in science and technology should be used as instruments of developmental progress (see also Bose 1997).
} 
project was consistently rationalised in colonial discourse as one that sought to bring the benefits of science and technology to a region that had been cut off from the modernising impulses of development. Furthermore, the project sought to bring about agricultural modernisation without rupturing the fabric of traditional rural communities. As Grischow (2001, p. 306) points out, this dimension of the project has to be understood in relation to the perceived need to ward off the challenges of movements such as Kwame Nkrumah's Convention People's Party: 'Inasmuch as unemployment and politicisation grew out of class formation, the preservation of community stood opposed to the growth of civil society'.

'Unlike other justifications for empire', Cooper (1998, p. 64) writes, 'development came to have as strong an appeal to nationalist elites as to colonisers'. What Cooper is referring to here is the emergence of development as an integral idiom in a discourse of entitlement that was mobilised by anti-colonial movements in Asia and Africa, and which would ultimately change the geopolitical shape of the world-capitalist system during the first half of the twentieth century: anti-colonial nationalism (see also Bose 1997). The lineage of the critique of colonial underdevelopment is arguably as long as that of the colonial development regime itself. Thus, in India, Dadabhai Naoroji developed a theory of the 'colonial drain of wealth' and formulated a searing indictment of the negative impacts of colonial rule on the country's development:

In reality there are two Indias - the one prosperous, the other poverty-stricken. The prosperous India is the India of the British and other foreigners. They exploit India as officials, non-officials, capitalists, in a variety of ways, and carry away enormous wealth to their own country ... The second India is the India of the Indians - the povertystricken India. This India is "bled" and exploited in every way of their wealth, of their services, of their land, labour and all resources by the foreigners, helpless and voiceless - this India of Indians becomes the poorest nation in the world (cited in Goswami 2004, p. 226). ${ }^{5}$

What Naoroji's critique signalled, of course, was the emergence of an oppositional discourse that fundamentally destabilised the colonial pretention to 'trusteeship' (Cowen and Shenton 1996) - that is, the idea that colonial rulers, by harnessing scientific and technical expertise to the task of governance in Asian and African territories, would put their subject territories on the path to developmental progress. At the core of this discourse was a claim that posited imperial power relations as the chief cause of underdevelopment in the colonies and argued that national self-determination would be a necessary precondition for progress. In so doing, anti-colonial economic nationalism fundamentally repoliticised the question of development.

Initially, of course, demands for national self-determination were articulated by native elites who 'made little attempt to mobilise the mass of the population into the nationalist struggle' (Silver and Slater 1999, p. 200). This changed between the First World War and the Second World War and in the aftermath of the revolutions in Mexico and Russia. During this period, peasants and workers joined the struggle for freedom from colonial rule en masse, while nationalist leaders increasingly coordinated their political projects between countries and across regions (Motta and Nilsen 2011; Prashad 2007). As the scope of mobilisation broadened, so too did the substantive content of anti-colonialism: the imperative of national liberation was wedded to ideals of social justice and an end to poverty. Anti-colonial

\footnotetext{
${ }^{4}$ As Grischow notes, this dimension of the project was ideologically rooted in the strong influence of Fabian theories of development on the Labour party's colonial policies (see also Kelemen 2007).

${ }^{5}$ See Chandra (2004) for an extended analysis of the rise of economic nationalism in India.
} 
movements, then, came to vindicate not just 'the liberty and equality of peoples', but also 'liberty and equality among the people' (Wallerstein 1990, p. 31; see also Silver and Slater 1999). This broadening was also inflected in anti-colonial imaginaries of development: whereas national liberation would make development a possibility, development, in turn, would put an end to poverty and injustice by making it possible — as Jawaharlal Nehru put it on the eve of India's independence in 1947- 'to create social, economic and political institutions which will ensure justice and fullness of life to every man and woman'.

\section{National Development Versus Popular Development}

With decolonisation, the collective oppositional project of anti-colonial nationalism gave way to national development regimes that were shaped in significant ways by important realignments of social forces at both national and global scales (Silver and Slater 1999; Patel and McMichael 2004; Desai 2004). At the national level, the newly independent countries witnessed the demobilisation of the mass movements that had carried forth anti-colonialism as an oppositional project; in exchange for political acquiescence, subaltern groups were offered greater access to expanded public employment and public services, as well as a minimal social wage guarantee through various forms of subsidised consumption (Walton and Seddon 1995). Simultaneously, at the global level, the world-system under US hegemony was restructured in such a way that the newly independent states of the Third World were in a position to articulate and implement development strategies geared towards modernisation that were characterised by a degree of separation between 'national and global market priorities' (Ludden 2005, p. 4046; see also Arrighi 1994).

Through this process, the idiom of development was repositioned as a central element in a new discourse of control and inflected with new meanings that diverged in crucial ways from its anti-colonial incarnation. Above all, development was once again depoliticised. As I argued above, development in its anti-colonial avatar had been construed as an objective that had to be fought for by popular movements in order to achieve social justice and an end to poverty. However, in the context of postcolonial nation-building, development increasingly came to be equated with what Timothy Mitchell (2002) has referred to as 'the rule of experts' - that is, as a goal that is to be achieved through policy interventions that are designed according to scientific expertise and selected according to objective criteria to drive non-partisan progress towards a putative national common good (see also Chatterjee 1993, pp. 201-205). At the scale of the nation-state, coalitions of state managers, industrial capital and landed elites retained the prerogative of giving form and direction to efforts in development planning that sought to fuse agricultural modernisation and import-substituting industrialisation in a drive towards modernisation (see Chibber 2003; Patel and McMichael 2004). At the international level, development was recast as a matter of 'democratic fair dealing' between a developed North and an underdeveloped South - predicated above all upon the former assisting the latter in 'a wider and vigorous application of modern scientific and technical knowledge' in the economic realm (Truman cited in Silver and Slater 1999, p. 208). Development assistance, however, came to constitute an integral element of the USA's Cold War armoury, coupled - as is evidenced in the bloody arc of US-backed military coups that stretches from Iran in 1953 (via Guatemala, Congo and Indonesia) to Chile in 1973 - by vigorously repressive policing to constrain transgressions of the narrow limits of capitalist nation-building (see Silver and Slater 1999).

The initial decades of the postcolonial era witnessed states in the Third World register some significant achievements in terms of the objectives of modernisation and growth: 'Between 
1950 and 1975 income per person in the developing countries increased on an average by 3 per cent p.a., accelerating from 2 per cent in the 1950 s to 3.4 per cent in the $1960 \mathrm{~s}$. This rate of growth was historically unprecedented for these countries and in excess of that achieved by the developed countries' (Glyn et al. 1991, p. 41). However, the structural underpinnings of these growth rates were riddled with contradictions and unevenness. In agriculture, some headway was made in terms of promoting land reform and technological innovation to boost capitalist farming and food production, but as Friedmann (1982) and McMichael and Raynolds (1994) have pointed out, countries in the global South remained dependent on importing food from the global North (see also Araghi 1995). Similarly, import-substituting industrialisation yielded mixed results: East Asian countries like Taiwan and South Korea experienced the emergence of potent industrial sectors, while other regions - for example, Latin America and South Asia-witnessed an economic trajectory in which domestic capitalists could socialise their risks and losses and privately appropriate the gains of growth: 'The end result was that there was development and growth - but at enormous cost to the public' (Chibber 2004, p. 239; see also Chibber 2003; Evans 1995; Kohli 2004; Kiely 2007a). And finally_as Colin Leys (1996) has pointed out - it was painfully evident that the global South still occupied a dependent and subordinate position in the political economy of the world system.

These contradictions finally came home to roost in the Southern moment of the global revolt of 1968 (see Wallerstein 2006) - a moment in which the regnant discourse of depoliticised development was fundamentally destabilised. This was a profoundly multifaceted moment, in which subaltern groups mobilised around oppositional projects that challenged both the contradictions of national development regimes and the continued subordination of Third World countries in the capitalist world system (Watts 2001; Berger 2004; Prashad 2007). A very significant facet of the 1968 revolt in the global South was the emergence of popular movements that targeted 'the nationalism and institutionalized elite politics ... of the first generation of independent Third-World states' (Watts 2001, p. 172). In India, for example, Adivasis, women, Dalits and informal sector workers mobilised outside the domain of electoral politics to challenge the centralisation of political power in an elitedominated state apparatus as well as the prevailing form and direction of development, which had dispossessed marginal peasants and subsistence producers, and failed to curtail the gendered and caste-based violence to which women and Dalits were still subjected (see Omvedt 1993). Parallel to the emergence of new social movements in the first generation of independent states in the Third World, protracted wars of national liberation gave rise to what Mark Berger (2004, p. 19) has called second-generation Bandung regimes. ${ }^{6}$ Cutting across the differences between these regimes was 'a more radical, more unambiguously socialist, Third Worldism' (Berger 2004: pp. 24-25) that resonated with the radicalism that was being espoused on the global arena through the call for a New International Economic Order (NIEO) articulated by the Non-Aligned Movement (see Prashad 2012).

The Southern moment of the global revolt of 1968 , then, was one in which social movements created a new discourse of entitlement centred on subaltern groups and popular classes within the independent states of the Third World who posited themselves as being entitled both to dignified livelihoods and political recognition and participation. In making these claims, social

\footnotetext{
${ }^{6}$ As a category, 'second-generation Bandung regimes' refers to an arc of regimes that ultimately stretches from Ahmed Ben Bella's Algeria (1962-1965) to Sandinista rule in Nicaragua (1979-1990). Other significant examples of this new generation of Third-World regimes would be Chile under Salvador Allende (19701973), Samora Machel's Mozambique (1975-1986) and Jamaica under Michael Manley (1972-1980).
} 
movements destabilised national development as a discourse of control by laying bare how developmental interventions that were claimed to serve a common national good systematically served the interests of dominant social forces, and at the same time - often in the form of 'oppositional populisms' (Gupta 2000, p. 34) - sought to vindicate alternative forms of development that would reflect and promote genuinely popular needs, interests and aspirations (see Nilsen 2015a, b). Similarly, the radicalised Third Worldism of the second-generation Bandung regimes and the NIEO project indicted the persistent subordination of Southern countries in the capitalist world-system, and thus challenged the legitimacy of the claim to fair dealing and development cooperation between North and South. And in arguing for a radical restructuring of the world economy in order to enable the Third World to break free from its subordinate and dependent position, the NAM articulated an alternative vision of global development - a vision in which the needs, interests and aspirations of Third World peoples would prevail over the power of Northern states in the world system (see Prashad 2012, pp. 24-34).

\section{The Revolt Against Neoliberal Development}

Ultimately, it was neither new social movements nor the NIEO project that would determine the course of Southern developmental trajectories. As is well known, the 1970s was a decade of crisis and transition that witnessed the onset of a major restructuring of the political economy of the capitalist world-system: the state-led forms of capitalist development that had prevailed since the end of the Second World War gave way to the market-led forms of capitalist development that we have now come to know as neoliberalism (see Harvey 2006; Peck 2010; Kiely 2004; Prashad 2012). In the global South, this process gained momentum in the late 1970s and early 1980s as postcolonial nation-building projects crumbled under the weight of international debts that had accumulated after the collapse of the Bretton Woods system in the early 1970s (Walton and Seddon 1994). Turning to the IMF and the World Bank for assistance in handling the crushing debt burden, states in the global South encountered a set of institutions whose policy preferences had come to be shaped by the neoliberal Washington Consensus (Peet 2007, pp. 109-113; Kiely 2004, pp. 68-77). According to this consensus, the key to solving the debt crisis lay in the adoption of market-centred reforms that were introduced through Structural Adjustment Programmes (SAPs) (Walton and Seddon 1994, pp. 17-19). Crucially, this process was not simply one in which policies were imposed upon the South by the North; rather, the orchestration of neoliberal restructuring was also shaped in important ways by the agency of Southern economic and political elites who sought to break with the project of national development (see Morton 2011; Chibber 2003; Connell and Dados 2014).

With the emergence of the neoliberal regime of development, a new discourse of control emerged in which development was posited as a goal that was to be achieved through integration in global market circuits: 'Countries that align themselves with the forces of globalisation and embrace the reforms needed to do so ... are likely to put themselves on a path of convergence with advanced economies' (IMF 1997, p. 72). However, the neoliberal regime of development extends beyond the macro-scale of political-economic restructuring in significant respects. This is evident, first of all, in how adjustment policies have been coupled with the promotion of forms of political governance and institution-building that can support the workings of the market (see Kiely 1998; Cammack 2004; Craig and Porter 2004; Soederberg 2005). Extending from the good governance agenda of the 1990s to the presentday emphasis on targeted social policies, this meso-scale of neoliberal restructuring ultimately represents 'a kind of pre-emptive, strategic inoculation against a more broadly and socially 
contested double movement, the kind of political double movement arguably most feared by the agents of a wider liberal project' (Craig and Porter 2006, p. 257). And finally, the neoliberal development regime extends to the micro-scale of individual bodies and subjectivities through development interventions such as micro-credit that seek to augment the ability of the poor to invest in their own human capital and to adopt the aptitudes of entrepreneurial subjects who 'selfmanage according to market principles of discipline, efficiency, and competitiveness' (Ong 2006, p. 7; see also Rankin 2001; Weber 2002; Elyachar 2005; Karim 2011; Keating et al. 2010; Roy 2010).

The claim that market integration promotes developmental convergence, however, has proven to be a fallacious one. Rather, this transition has thrown up a new geography of production in which regions and states in the global South still occupy subordinate positions (see Kiely 2007b) and has expanded the reach of the market logic in such a way as to facilitate the transfer of assets, wealth and income 'from the mass of the population to the upper classes [and] from vulnerable to richer countries' (Harvey 2007, p. 34). Uneven development therefore persists in the capitalist world-system - manifest above all in deepening inequalities and the emergence of a 'surplus population' of rural and urban poor, which is relegated 'to irregular, insecure, temporary and precarious forms of employment' (Neilson and Stubbs 2011, p. 436) or altogether marginalised from labour markets in an age of unprecedented levels of unemployment (see McIntyre and Nast 2011; Duffield 2007, Chap. 1; Davis 2006). Furthermore, neoliberal interventions such as micro-credit, which typically target these surplus populations in order to identity 'new subjects of development' and open up and consolidate 'new territories of investment' (Roy 2010, p. 218) have been found to do little to challenge the structures that generate poverty in the global political economy (Bateman 2010; Karim 2011; Taylor 2011).

Popular social forces in the global South have contested the neoliberal development regime from its early origins until its present crisis-ridden impasse. Initial subaltern resistance to neoliberalism took the form of 'IMF riots' and 'austerity protests', which rallied the urban poor, the working classes and at times also segments of the middle classes in opposition to the distributional outcomes of SAPs (Walton and Seddon 1994, pp. 39-44). The politics of the IMF riots were essentially defensive: austerity protests were geared towards upholding facets of the state-society relations of the postcolonial development project that accommodated the needs and interests of subaltern groups - primarily the social wage guarantees that postcolonial states had provided in exchange for political acquiescence in the wake of decolonisation (Walton and Seddon 1994, pp. 48-50; see also Motta and Nilsen 2011, p. 14). The phasing out of these guarantees in connection with SAPs was experienced as a violation of rightful entitlements among the popular classes: 'Protestors demanded that the state meet its responsibilities to the people who, during the decades of patron-client politics, had upheld their end of the bargain' (Walton and Seddon 1994, p. 50).

Ultimately, what the IMF riots of the 1980s and early 1990s signalled was the emergence of a new discourse of entitlement that would ultimately crystallise in the oppositional projects of the social movements that had consolidated across much of the global South by the early $2000 \mathrm{~s}$ (Nilsen 2015a, b). These movements mobilised a wide array of subaltern groups (peasants and landless workers, women, informal sector workers, unemployed workers, slum dwellers, indigenous peoples, and marginalised youth) around sets of radical claims and practices that - taken together - challenged the anti-politics of the neoliberal development regime in significant ways (see Motta and Nilsen 2011; Nilsen 2015a). This is reflected, first of all, in the ways in which resistance to dispossession is increasingly linked to the crafting of alternative forms of collective ownership - for example, in the form of the worker-run factories organised 
by the Movimiento de Trabajadores Desocupados in Argentina or the cooperatives of the Movimento dos Trabalhadores Sem Terra in Brazil (see, for example, Dinerstein 2002; Schaumberg 2008; Wright and Wolford 2003; Vergara-Camus 2014). Secondly, the transcendence of neoliberal development finds expression in the way in which social movements promote more participatory and deliberative forms of political decision-making - for example, in and through the practices of movements of the urban poor, such as the Comités de Tierra Urbana in Venezuela and Abahlali baseMjondolo in South Africa (see, for example, Motta 2011; Cicciarello-Maher 2011; Garciá-Guadilla 2011; Gibson 2008; Pithouse 2008; Brown 2015). Thirdly, neoliberal development is challenged by the ways in which social movements in the global South link localised struggles to the dynamics of global power structures and mobilise to achieve progressive changes across spatial scales - for example, when transnational agrarian movements fuse the struggles of rural communities in opposition to neoliberal 'food regimes' or when technocratic climate change negotiations are contested by demands for climate justice (see, for example, Edelman and Kay 2008; Borras 2010; Goodman 2009; Chatterton et al. 2013).

\section{Studying Struggles Over Development}

The broad sweep presented above has sought to make a very basic but also very important point, namely that across key conjunctures of struggle and transformation, development has simultaneously been at the centre of both discourses of control mobilised by dominant social forces and discourses of entitlement mobilised by subaltern social forces. My central argument is that it is through the study of this constant dialectic of depoliticisation and repoliticisationrather than through a simple opposition of an all-powerful Eurocentric discourse to autonomous assertions of otherness - that we should ground critical engagements with development. However, in studying struggles over development, it is necessary to go beyond this bird's eye view and move towards a more fine-grained investigation of the dynamics that unfold when social movements appropriate the idiom of development and embed it as a central element in their oppositional projects. In doing so, we will find that social movements do not constitute bounded entities within which political unanimity prevails; on the contrary, any given social movement exists as a fluid field with blurred boundaries, whose internal dynamics are animated by contentious negotiations and problematic power relations, and whose participants are 'capable of reading different, divergent, and potentially contradictory meanings' into a given discourse of entitlement (Steinberg 1999, p. 741; see also Nash 1992; Wolford 2010; Cox 1999). In lieu of a conclusion, I will draw this article to an end with a discussion of how this process manifested itself in my own research on the Narmada Bachao Andolan and its mobilisation against large dams in central and western India. ${ }^{7}$

My initial exploration of the politics of the NBA started some 15 years ago, when, as an undergraduate student, I wanted to investigate how social movements build alternative visions of development. I first became aware of the anti-dam movement in the Narmada Valley through Arundhati Roy's (2002) essay 'The Greater Common Good', and established contact with the movement through its international network of supporters. My first actual foray into the field started at the movement's offices in the city of Baroda, where I met and interacted directly with leading activists, all of whom were highly educated and spoke English, and was given a number of pamphlets and documents about the Andolan and its politics. From the city

$\overline{{ }^{7} \text { See Nilsen }(2007,2008,2010,2013) .}$ 
offices I proceeded - in the company of leading activists and a large group of other researchers, journalists, filmmakers and international supporters - to Adivasi villages that were slated for submergence by the Sardar Sarovar dam in order to participate in the annual satyagraha, a protest action in which activists would brave the rising waters of the Narmada as a sign of defiance against what was termed 'destructive development'. By participating in and observing protest events and constructive activities in the submergence zone of the dam, and by reading closely the pamphlets and documents that I had been provided with, I started to discern the contours of an oppositional project that did not reject development, but which sought to reclaim and reinvent an alternative form of development centred on participatory democracy, environmental sustainability and social justice (see Nilsen 2010, pp. 171-81).

I then pursued my study of the NBA further through my doctoral research, which enabled me to spend a longer period of time in the Narmada Valley and to interact with a wide range of activists in the villages in the submergence zone - both Adivasis in the hilly regions and casteHindu farmers in the plains of western Madhya Pradesh. As this work progressed, I started to unearth layers and fault lines within the movement which had not been apparent to me in my initial round of research, and which problematised my perception of the movement as being unified around a carefully crafted vision of alternative development that was opposed both to postcolonial nation-building and to neoliberal restructuring.

One of the things I noticed was that different groups of activists articulated their ideas of alternative development in very different ways: urban educated activists, often hailing from a middle class background, would espouse the ideas that I had encountered in the NBA's pamphlets and documents; Adivasi activists - many of whom were illiterate - tended to speak much more concretely of the pressing need for secure employment, access to education and healthcare, and improved infrastructure; farmers in the caste Hindu villages - many of whom were quite prosperous - argued that the state would have to prioritise agriculture and bring back subsidies, support prices and market protection. It also became clear to me that the Andolan's involvement with nation-wide networks of social movements - for example, the Jan Vikas Andolan and the National Alliance of People's Movements - and the efforts of these networks to articulate comprehensive programmes centred on an alternative conception of development did not resonate with the exigencies that Adivasi activists confronted in their own lifeworlds (see Nilsen 2010, pp. 182-87). In other words, within the NBA itself, the idiom of development was imbued with different meaning by different participants in the movement (see also Baviskar 1995).

Furthermore, I also started to see how community participation in the Andolan was shaped by relations of power that were hardly commensurable with the movement's professed belief in social justice. This was particularly so in relation to the caste Hindu farming communities in the Nimad plains of western Madhya Pradesh. In these village communities, local leadership of the Andolan was overwhelmingly concentrated among relatively rich farmers, most of whom were Patidars by caste. These activists would frame resistance to displacement as an issue around which the entire community was united, and the conflict in the Narmada Valley as one that pitted city and industry against countryside and agriculture. ${ }^{8}$ Crucially, they would also portray the villages as harmonious entities, where relations between different castes and classes were characterised by harmony and conviviality, and free from exploitation and oppression. An altogether different picture emerged from conversations with landless labourers in the village,

\footnotetext{
${ }^{8}$ In arguing along these lines, the Nimad activists were echoing the discourse of India's New Farmer's Movements, which posited a fundamental conflict as running between a rural 'Bharat' and an 'urban' India, in which the former is exploited by the latter (see, for example, Banaji 1998).
} 
many of whom were Dalits. Whereas they had some sympathy for the struggle against displacement, they would typically argue that this was an issue first and foremost for the landowning farmers. It was also clear from their accounts that their participation in the movement mostly took the form of attending large-scale rallies, often at the orders of their employers and social superiors. They argued that caste-based oppression was still operative in the villages, and that they suffered under highly exploitative working conditions (see Nilsen 2010, pp. 158-68).

My 'discovery' of multiple layers and fault lines within the NBA resonates with what other scholars have found through ethnographic studies of social movements involved in struggles over development. For example, in her compelling study of the MST in Brazil, Wolford (2010, p. 19) unearths different and conflicting 'localized moral economies' among different groups of movement participants: in Southern Brazil, she finds that small peasants had joined the movement in order to uphold a long-standing way of life based on small-scale farming, whereas in Northeast Brazil, the movement's membership was largely made up of displaced workers from the sugarcane industry, who joined the MST in a desperate effort to secure a livelihood. Whereas the former group of participants aligned themselves to the MST's project of alternative development centred around cooperative production on occupied agricultural land, the latter group found it difficult to do so, and preferred to make their living on the basis of wage labour. 'Even those who did want to work on the land', Wolford (2010, p. 19) writes, 'attributed very different meanings to their work than the meanings that were promoted by movement leaders and that were hegemonic among members in the South of the country'.

On first sight, findings such as these can seem to pose critical researchers with a thorny ethical dilemma. Writing about the infrapolitics of social movements could entail running the risk of contributing to discrediting or delegitimising oppositional projects that are geared towards emancipatory change; thus, in doing so, we would arguably betray our solidarities and our commitment to producing knowledge that is relevant to the political and strategic needs and interests of social movements. However, there is also a very real sense in which this is a false dilemma. If we depart from the assumption that social movements are criss-crossed by power relations, negotiated agreements between various groups of participants, and political and strategic tensions - that is, the kind of assumption which has informed the work of scholars such as Alain Touraine (1981) and Alberto Melucci (1987) in the European context - then it is also possible to approach the mapping and analysis of these fault lines in ways that are in keeping with the ambition of producing knowledge that is relevant to the oppositional projects that movements are trying to build and pursue (see also Cox 2014). In practical terms, this entails, first and foremost, relating to our findings and our analyses not as evidence of ethnographic prowess through which we can gain academic recognition, but as contributions to ongoing debates and dialogues within the movements that we engage with. Furthermore, pursuing such an approach entails recognising that if we choose to avoid engagement with 'all the local categories of friction and tension' (Ortner 1995, p. 177) that traverse social movements and subaltern communities we are in effect choosing to privilege 'some subalterns over others' (Wolford 2010, p. 12) in a way which ultimately militates against the need for democratic deliberation to be at the heart of the making of oppositional projects for emancipatory transformation. In the context of struggles over development, this means, most fundamentally, to raise questions about what it entails for social movements and their oppositional projects that different groups of participants conceive of the direction and meaning of development in different ways, and what the implications are of the fact that some voices tend to prevail over others in defining what kind of alternative development a movement project should strive towards. 
In other words, critical research-like activism - should not shy away from mapping and engaging with the fault lines and contradictions of oppositional political projects. But our engagement should be informed by a notion of solidarity, in which our analyses are geared to speaking to ongoing debates and processes within these social movements, rather than a scholastic compulsion to display ethnographic competence. The ways in which we seek to make our research relevant to activist needs will vary immensely, depending, inter alia, on the character of the relationships we build with specific social movements, the internal dynamics of these movements, and the specific conjunctures of contention in which we carry out or research. In other words, there is no singular method that will enable us to realise such an ambition - only a constant challenge that we will have to negotiate time and again, in a process of learning by doing that is in itself an oppositional project.

Open Access This article is distributed under the terms of the Creative Commons Attribution 4.0 International License (http://creativecommons.org/licenses/by/4.0/), which permits unrestricted use, distribution, and reproduction in any medium, provided you give appropriate credit to the original author(s) and the source, provide a link to the Creative Commons license, and indicate if changes were made.

\section{References}

Araghi, F. (1995). Global depeasantization, 1945-1990. The Sociological Quarterly, 36(3), 337-368.

Arrighi, G. (1994). The long twentieth century: money, power and the origins of our times. London: Verso.

Banaji, J. (1998). The farmers' movements: a critique of conservative rural coalitions. Journal of Peasant Studies, 21(3-4), 228-245.

Bateman, M. (2010). Why doesn't microfinance work? The destructive rise of local neoliberalism. London: Zed Books.

Baviskar, A. (1995). In the belly of the river: tribal conflicts over development in the Narmada valley. New Delhi: Oxford University Press.

Berger, M. T. (2004). After the third world: history, destiny and the fate of third worldism. Third World Quarterly, 25(1), 9-39.

Beusekom, M. (1997). Colonisation indigène: French rural development ideology at the office du Niger, 19201940. The International Journal of African Historical Studies, 30(2), 299-323.

Beusekom, M., \& Hodgson, D. (2000). Lessons learned? Development experiences in the late colonial period. The Journal of African History, 41(1), 29-33.

Bhambra, G. (2007). Rethinking modernity: postcolonialism and the sociological imagination. London: Palgrave.

Bhambra, G. (2014). Connected sociologies. London: Bloomsbury Academic Press.

Borras, S. (2010). The politics of transnational agrarian movements. Development and Change, 41(5), 771-803.

Bose, S. (1997). Instruments and idioms of colonial and national development: India's historical experience in comparative perspective. In F. Cooper \& R. Packard (Eds.), International development and the social sciences: essays on the history and politics of knowledge (pp. 45-63). Berkeley: University of California Press.

Brigg, M. (2002). Post-development, Foucault and the colonisation metaphor. Third World Quarterly, 23(3), $421-436$.

Brohman, J. (1995). Universalism, eurocentrism, and ideological bias in development studies: from modernisation to neoliberalism. Third World Quarterly, 16(1), 121-162.

Brown, J. (2015). South Africa's insurgent citizens: on dissent and the possibility of politics. London: Zed Books.

Cammack, P. (2004). What the World Bank means by poverty reduction, and why It matters. New Political Economy, 9(2), 189-211.

Chatterjee, P. (1993). The nation and its fragments. Princeton: Princeton University Press.

Chandra, B. (2004). The rise and growth of economic nationalism in India: economic policies of Indian national leadership, 1880-1905. New Delhi: Hindustan Publishing Company.

Chatterton, P., Featherstone, D., \& Routledge, P. (2013). Articulating climate justice in Copenhagen: antagonism, the commons, and solidarity. Antipode, 45(3), 602-620.

Chibber, V. (2003). Locked in place: state-building and late industrialization in India. Princeton: Princeton University Press. 
Chibber, V. (2004). Reviving the developmental state: the myth of 'the national bourgeoisie. Socialist Register, $41,144-165$.

Cicciarello-Maher, G. (2011). We Created Chavez: A People's History of the Venezuelan Revolution. Durham: Duke University Press.

Connell, R., \& Dados, N. (2014). Where in the world does neoliberalism come from? The market agenda in southern perspective. Theory and Society, 43(2), 117-138.

Cooper, F. (1997). Modernizing bureaucrats, backward Africans, and the development concept. In F. Cooper \& R. Packard (Eds.), International development and the social sciences: essays on the history and politics of knowledge (pp. 6-92). Berkeley: University of California Press.

Cooper, F., \& Packard, R. (1997). Introduction. In F. Cooper \& R. Packard (Eds.), International development and the social sciences: essays on the history and politics of knowledge (pp. 1-43). Berkeley: University of California Press.

Corbridge, S. (1998). 'Beneath the pavement only soil': the poverty of post-development. Journal of Development Studies, 34(6), 138-148.

Cowen, M., \& Shenton, R. W. (1996). Doctrines of development. London: Routledge.

Cox, L. (1999). Power, politics and everyday life: the local rationalities of social movement milieux. In P. Bagguley \& J. Hearn (Eds.), Transforming politics: power and resistance (pp. 43-66). Basingstoke: Macmillan.

Cox, L. (2014). Movements making knowledge: a new wave of inspiration for sociology? Sociology, 48(5), 954-971.

Cox, L., \& Nilsen, A. G. (2014). We make our own history: Marxism and social movements in the twilight of neoliberalism. London: Pluto Press.

Craig, D., \& Porter, D. (2004). The third way and the third world: poverty reduction and social inclusion in the rise of 'inclusive' liberalism. Review of International Political Economy, 11(2), 387-423.

Craig, D., \& Porter, D. (2006). Development beyond neoliberalism: governance, poverty reduction, and political economy. London: Routledge.

Crush, J. S. (1995). The power of development. London: Routledge.

Davis, M. (2002). Late Victorian holocausts: El niño famines and the making of the third world. London: Verso.

Davis, M. (2006). Planet of slums. London: Verso.

Desai, R. (2004). From national bourgeoisies to rogues, failures, and bullies: 21st century imperialism and the unravelling of the Third World. Third World Quarterly, 25(1), 169-185.

De Vries, P. (2007). Don't compromise your desire for development! A Lacanian/Deleuzian rethinking of the anti-politics machine. Third World Quarterly, 28(1), 25-43.

Dinerstein, A. C. (2002). The battle of Buenos Aires: crisis, insurrection and the reinvention of politics in Argentina. Historical Materialism, 10(4), 5-38.

Duffield, M. (2007). Development, security and unending war: governing the world of peoples. Cambridge: Polity Press.

Edelman, M., \& Kay, C. (2008). Transnational agrarian movements: origins and politics, campaigns and impact. Journal of Agrarian Change, 8(2-3), 169-204.

Elyachar, J. (2005). Markets of dispossession: NGOs, economic development, and the state in Cairo. Durham: Duke University Press.

Escobar, A. (1995). Encountering development: the making and unmaking of the third world. Princeton: Princeton University Press.

Esteva, G., Babones, S. J., \& Babkicky, B. (2013). The future of development: a radical manifesto. Bristol: Policy Press.

Evans, P. B. (1995). Embedded autonomy: states and industrial transformation. Princeton: Princeton University Press.

Ferguson, J. (1990). The anti-politics machine: development, depoliticization and bureaucratic power in Lesotho. Minneapolis: University of Minnesota Press.

Friedmann, H. (1982). The political economy of food: the rise and fall of the postwar international food order. American Journal of Sociology, 88, 248-286.

Garciá-Guadilla, M. P. (2011). Urban land committees: cooptation, autonomy and protagonism. In D. Smilde \& D. Hellinger (Eds.), Venezuela's Bolivarian democracy (pp. 80-103). Durham: Duke University Press.

Gibson, N. C. (2008). Introduction: a new politics of the poor Emerges from South Africa's shantytowns. Journal of Asian and African Studies, 43(1), 5-17.

Gidwani, V. (2002). The unbearable modernity of 'development'? Canal irrigation and development planning in Western India. Progress in Planning, 58(1), 1-80.

Glyn, A., Hughes, A., Lipietz, A., \& Singh, A. (1991). The rise and fall of the golden age. In S. A. Marglin \& J. B. Schor (Eds.), The golden age of capitalism: reinterpreting the postwar experience (pp. 39-125). Oxford: Clarendon Press.

Goodman, J. (2009). From global justice to climate justice? Justice ecologism in an era of global warming. New Political Science, 31(4), 499-514. 
Goswami, M. (2004). Producing India: from colonial economy to national space. Chicago: University of Chicago Press.

Gramsci, A. (1998). Selections from the prison notebooks. London: Lawrence and Wishart.

Grischow, J. D. (2001). Late colonial development in British West Africa: the Gonja development project in the Northern Territories of the Gold Coast, 1948-57. Canadian Journal of African Studies, 35(2), 282-312.

Gupta, A. (2000). Postcolonial developments: agriculture in the making of modern India. Durham: Duke University Press.

Harriss, J. (2007). Bringing politics back in to poverty analysis: why understanding of social relations matters more for policy on chronic poverty than measurement. Paper available from https:/www.trentu.ca/ids/ documents/Q2_WP34_Harriss.pdf

Hart, G. (2001). Development critiques in the 1990s: Culs de sac and promising paths. Progress in Human Geography, 25(4), 649-658.

Harvey, D. (2006). A brief history of neoliberalism. Oxford: Oxford University Press.

Harvey, D. (2007). Neoliberalism as creative destruction. Annals of the American Academy of Political Science, $610(1), 22-44$.

Hickey, S., \& Du Toit, A. (2014). Social exclusion, adverse incorporation and chronic poverty. In A. Shepherd \& J. Brunt (Eds.), Chronic poverty (pp. 134-159). London: Palgrave.

Hodgson, D. (2000). Taking stock: State control, ethnic identity and pastoralist development in Tanganyika, 1948-1958. The Journal of African History, 41(1), 55-78.

IMF. (1997). World economic outlook - May 1997. Washington: International Monetary Fund.

Karim, L. (2011). Microfinance and its discontents: women in debt in Bangladesh. Minneapolis: Minnesota University Press.

Keating, C., Rasmussen, C., \& Rishi, P. (2010). The rationality of empowerment: microcredit, accumulation by dispossession, and the gendered economy. Signs, 36(1), 153-176.

Kelemen, P. (2007). Planning for Africa: the British Labour Party's colonial development policy,1920-1964. Journal of Agrarian Change, 7(1), 76-98.

Kiely, R. (1998). Neoliberalism revised? A critical account of World Bank conceptions of good governance and market friendly intervention. International Journal of Health Services, 28(4), 683-702.

Kiely, R. (1999). The last refuge of the noble savage? A critical assessment of post-development theory. European Journal of Development Research, 11(1), 30-55.

Kiely, R. (2004). The clash of globalisations: neo-liberalism, the third way and anti-globalisation. Leiden: Brill.

Kiely, R. (2007a). The new political economy of development: globalization, imperialism, hegemony. London: Palgrave.

Kiely, R. (2007b). Poverty reduction through liberalisation? Neoliberalism and the myth of global convergence. Review of International Studies, 33(3), 415-34.

Kohli, A. (2004). State-directed development: political power and industrialization in the global periphery. Cambridge: Cambridge University Press.

Leys, C. (1996). The rise and fall of development theory. London: James Currey.

Li, T. M. (1999). Compromising power: development, culture and rule in Indonesia. Cultural Anthropology, $14(3), 295-322$.

Li, T. M. (2007). The will to improve: governmentality, development, and the practice of politics. Durham: Duke University Press.

Ludden, D. (1992). India's development regime. In N. Dirks (Ed.), Colonialism and culture (pp. 247-288). Ann Arbor: University of Michigan Press.

Ludden, D. (2005). Development regimes in South Asia: history and the governance conundrum. Economic and Political Weekly, 40(37), 4042-4051.

Mallon, F. E. (1995). Peasant and nation: the making of postcolonial Mexico and Peru. Berkeley: University of California Press.

Marx, K. (1990). Capital: a critique of political economy: volume 1. Harmondsworth: Penguin.

McIntyre, M., \& Nast, H. (2011). Bio(necro)polis: surplus populations, and the spatial dialectics of reproduction and "race". Antipode, 43(5), 1465-1488.

McMichael, P., \& Raynolds, D. (1994). Capitalism, agriculture and world economy. In L. Sklair (Ed.), Capitalism and development (pp. 316-338). London: Routledge.

Melucci, A. (1987). Nomads of the present: social movements and individual needs in contemporary society. Philadelphia: Temple University Press.

Mitchell, T. (2002). Rule of experts: Egypt, techno-politics, modernity. Berkeley: University of California Press.

Moore, D. S. (1998). Subaltern struggles and the politics of place: remapping resistance in Zimbabwe's eastern highlands. Cultural Anthropology, 13(3), 1-38.

Moore, D. S. (1999). The crucible of cultural politics: reworking "development" in Zimbabwe's eastern highlands. American Ethnologist, 26(3), 654-689. 
Morton, A. D. (2011). Revolution and state in Mexico: the political economy of uneven development. Lanham: Rowman and Littlefield Publishers.

Mosse, D. (2010). A relational approach to durable poverty, inequality and power. Journal of Development Studies, 46(7), 1156-1178.

Motta, S. C. (2011). Populism's Achilles' heel: popular democracy beyond the liberal state and the market economy in Venezuela. Latin American Perspectives, 38(176), 28-46.

Motta, S. C., \& Nilsen, A. G. (2011). Social movements and/in the postcolonial: dispossession, development and resistance in the global south. In S. C. Motta \& A. G. Nilsen (Eds.), Social movements in the global South: dispossession, development and resistance (pp. 1-31). London: Palgrave Macmillan.

Nash, J. (1992). Interpreting social movements: Bolivian resistance to economic conditions imposed by the International Monetary Fund. American Ethnologist, 19(2), 275-293.

Neilson, D., \& Stubbs, T. (2011). Relative surplus population and uneven development in the Neoliberal Era: theory and empirical application. Capital and Class, 35(3), 435-453.

Nilsen, A. G. (2007). On new social movements and 'the reinvention of India'. Forum for Development Studies, 34(2), 271-293.

Nilsen, A. G. (2008). Political economy, social movements and state power: a Marxian perspective on two decades of resistance to the Narmada dams. Journal of Historical Sociology, 21(2-3), 303-330.

Nilsen, A. G. (2010). Dispossession and resistance in India: the river and the rage. London: Routledge.

Nilsen, A. G. (2013). Against the current; from below: resisting dispossession in the Narmada Valley, India. Journal of Poverty, 17(4), 460-492.

Nilsen, A. G. (2015a). Postcolonial social movements. In I. Ness \& Z. Cope (Eds.), The Palgrave encyclopedia of imperialism and anti-imperialism (pp. 932-938). New York: Palgrave.

Nilsen, A. G. (2015b). For a historical sociology of state-society relations in the study of subaltern politics. In A. G. Nilsen \& S. Roy (Eds.), New subaltern politics: reconceptualizing hegemony and resistance in contemporary India (pp. 31-53). Delhi: Oxford University Press.

Omvedt, G. (1993). Reinventing revolution: new social movements and the socialist tradition in India. New York: East Gate.

Ong, A. (2006). Neoliberalism as exception: mutations in citizenship and sovereignty. Durham: Duke University Press.

Ortner, S. (1995). Resistance and the problem of ethnographic refusal. Comparative Studies in Society and History, 37(1), 173-193.

Patel, R., \& McMichael, P. (2004). Third worldism and the lineages of global fascism: the regrouping of the global south in the Neoliberal Era. Third World Quarterly, 25(1), 231-254.

Peck, J. (2010). Constructions of neoliberal reason. London: Oxford University Press.

Peet, R. (2007). Unholy trinity: the IMF, World Bank and WTO. London: Zed Books.

Pieterse, J. N. (1998). My paradigm or yours? Alternative development, post-development, reflexive development. Development and Change, 29(2), 343-373.

Pieterse, J. N. (2000). After post-development. Third World Quarterly, 21(2), 171-195.

Pithouse, R. (2008). A politics of the poor: Shack dwellers' struggles in Durban. Journal of Asian and African Studies, 43(1), 63-94.

Prashad, V. (2007). The darker nations: a biography of the short-lived third world. New Delhi: Leftword Books.

Prashad, V. (2012). The poorer nations: a possible history of the global south. London: Verso.

Rahnema, M., \& Bawtree, V. (1997). The post-development reader. London: Zed Books.

Rangan, H. (2000). Of myths and movements: rewriting Chipko into Himalayan history. Delhi: Oxford University Press.

Rankin, K. (2001). Governing development: neoliberalism, microcredit and rational economic woman. Economy and Society, 30(1), 18-37.

Rankin, K. (2009). Critical development studies and the praxis of planning. City, 13(2-3), 219-229.

Rediker, M., \& Linebaugh, P. (2001). The many-headed hydra: sailors, slaves, commoners, and the hidden history of the revolutionary Atlantic. London: Verso.

Roseberry, W. (1994). Hegemony and the languages of contention. In G. M. Joseph \& D. Nugent (Eds.), Everyday forms of state formation: revolution and the negotiation of rule in modern Mexico (pp. 355-366). Durham: Duke University Press.

Roy, A. (2002). The algebra of infinite justice. New Delhi: Penguin.

Roy, A. (2010). Poverty capital: microfinance and the making of development. London: Routledge.

Sachs, W. (Ed.). (1992). The development dictionary. London: Zed Books.

Said, E. (1978). Orientalism. New York: Pantheon Books.

Sandbrook, R., Edelman, M., Heller, P., \& Teichman, J. (2010). Social democracy in the global periphery: origins, challenges, prospects. Cambridge: Cambridge University Press. 
Sardar, Z. (1999). Development and the locations of eurocentrism. In R. Munck \& D. O'Hearn (Eds.), Critical development theory: contributions to a new paradigm (pp. 44-62). London: Zed Books.

Schaumberg, H. (2008). In search of alternatives: the making of grassroots politics and power in Argentina. Bulletin of Latin American Research, 27(3), 368-387.

Shakya, Y. B., \& Rankin, K. (2008). The politics of subversion in development practice: an exploration of microfinance in Nepal and Vietnam. Journal of Development Studies, 44(8), 1214-1235.

Sharma, A. (2008). Logics of empowerment: development, gender, and governance in neoliberal India. Minneapolis: Minnesota University Press.

Silver, B., \& Slater, E. (1999). The social origins of world hegemonies. In G. Arrighi \& B. Silver (Eds.), Chaos and governance in the world system (pp. 151-216). Minneapolis: University of Minnesota Press.

Sinha, S. (2003). Development counter-narratives: taking social movements seriously. In K. Sivaramakrishnan \& A. Agrawal (Eds.), Regional modernities: the cultural politics of development in India (pp. 286-312). Stanford: Stanford University Press.

Smyth, R. (2004). The roots of community development in colonial office policy and practice in Africa. Social Policy and Administration, 38(4), 418-436.

Soederberg, S. (2005). Recasting neoliberal dominance in the global south? A critique of the Monterrey consensus. Alternatives, 30(3), 325-364.

Steinberg, M. W. (1999). The talk and back talk of collective action: a dialogic analysis of repertoires of discourse among nineteenth-century English cotton spinners. American Journal of Sociology, 105(3), 736-780.

Taylor, M. (2011). 'Freedom from poverty is not for free': rural development and the microfinance crisis in Andhra Pradesh, India”. Journal of Agrarian Change, 11(4), 484-504.

Touraine, A. (1981). The voice and the eye: an analysis of social movements. Cambridge: Cambridge University Press.

Vergara-Camus, L. (2014). Land and freedom: the MST, the Zapatistas and peasant alternatives to neoliberalism. London: Zed Books.

Wallerstein, I. (1990). Anti-systemic movements: history and dilemmas. In S. Amin, G. Arrighi, A. G. Frank, \& I. Wallerstein (Eds.), Transforming the revolution: social movements and the world system (pp. 13-53). New York: Monthly Review Press.

Wallerstein, I. (2006). The curve of American power. New Left Review, 40, 77-94.

Walton, J., \& Seddon, D. (1994). Free markets and food riots: the politics of global adjustment. Oxford: Blackwell.

Walton, J., \& Seddon, D. (1995). Free markets \& food riots: the politics of global adjustment. Oxford: Blackwell Publishers.

Watts, M. (2001). 1968 and all that .... Progress in Human Geography, 25(2), 157-188.

Weber, H. (2002). The imposition of a global development architecture: the example of microcredit. Review of International Studies, 28(3), 537-555.

Wolford, W. (2010). This land is ours now: social mobilization and the meanings of land in Brazil. Durham: Duke University Press.

Worby, E. (2000). 'Discipline without oppression': sequence, timing and marginality in southern Rhodesia's post-war development regime. The Journal of African History, 41(1), 101-125.

Wright, A. L., \& Wolford, W. (2003). To inherit the earth: the landless movement and the struggle for a new Brazil. Berkeley: Food First. 